\title{
DESIGN, IMPLEMENTATION AND VERIFICATION OF SOFTWARE CODE FOR RADIATION DOSE ASSESSMENT BASED ON SIMPLE GENERIC ENVIRONMENTAL MODEL
}

\author{
I Putu Susila $^{1}$, Arif Yuniarto ${ }^{2}$ \\ ${ }^{1}$ Center for Nuclear Engineering Facility - BATAN, Puspiptek Area, Setu, Tangerang Selatan, 15310 \\ ${ }^{2}$ Center for Empowerment of Informatics and Nuclear Strategic Area - BATAN, Puspiptek Area, Setu, \\ Tangerang Selatan, 15310 \\ Diterima editor: 23 Mei 2017 \\ Diperbaiki: 12 Juni 2017 \\ Disetujui untuk publikasi: 13 Juni 2017
}

\begin{abstract}
DESIGN, IMPLEMENTATION AND VERIFICATION OF SOFTWARE CODE FOR RADIATION DOSE ASSESSMENT BASED ON SIMPLE GENERIC ENVIRONMENTAL MODEL. Radiation dose assessment to determine the potential of radiological impacts of various installations within nuclear facility complex is necessary to ensure evironmental and public safety. A simple generic model-based method for calculating radiation doses caused by the release of radioactive substances into the environment has been published by the International Atomic Energy Agency (IAEA) as the Safety Report Series No. 19 (SRS-19). In order to assist the application of the assessment method and a basis for the development of more complex assessment methods, an open-source based software code has been designed and implemented. The software comes with maps and is very easy to be used because assessment scenarios can be done through diagrams. Software verification was performed by comparing its result to SRS-19 and CROM software calculation results. Dose estimated by SRS-19 are higher compared to the result of developed software. However, these are still acceptable since dose estimation in SRS-19 is based on conservative approach. On the other hand, compared to CROM software, the same results for three scenarios and a non-significant difference of $2.25 \%$ in another scenario were obtained. These results indicate the correctness of our implementation and implies that the developed software is ready for use in real scenario. In the future, the addition of various features and development of new model need to be done to improve the capability of software that has been developed.
\end{abstract}

Keywords: Radiation dose assessment, software code, radioactive discharge, environment, IAEA SRS-19.

\section{ABSTRAK}

PERANCANGAN, IMPLEMENTASI DAN VERIFIKASI PERANGKAT LUNAK UNTUK KAJIAN DOSIS RADIASI BERBASIS MODEL LINGKUNGAN GENERIK SEDERHANA. Kajian dosis radiasi untuk mengetahui potensi dampak radiologi akibat pengoperasian berbagai instalasi yang ada di dalam kawasan instalasi nuklir sangat diperlukan untuk menjamin keselamatan masyarakat dan lingkungan. Metode sederhana berbasis model lingkungan generik untuk menghitung dosis radiasi yang disebabkan oleh pelepasan zat radioaktif ke lingkungan telah diterbitkan oleh International Atomic Energy Agency (IAEA) sebagai Safety Report Series No. 19 (SRS-19). Untuk lebih memudahkan penerapan metode tersebut, maupun sebagai dasar kajian serta pengembangan metode yang lebih kompleks, maka dilakukan perancangan dan implementasi perangkat lunak terkait berbasis open-source. Perangkat lunak yang dibuat telah dilengkapi dengan peta serta sangat mudah digunakan karena skenario kajian dosis radiasi dapat dibuat melalui diagram. Verifikasi melalui komparasi dengan nilai hasil perhitungan di SRS-19 serta hasil perhitungan perangkat lunak CROM. Hasil komparasi dengan SRS-19 menunjukkan adanya perbedaan pada empat skenario yang diuji. Hal ini wajar karena pada SRS19 perhitungan dilakukan dengan pendekatan konservatif sehingga nilai dosis yang dihasilkan lebih besar jika dibandingkan dengan perangkat lunak yang dikembangkan. Selanjutnya, pada komparasi dengan perangkat lunak CROM, keduanya menunjukkan hasil yang sama pada tiga skenario serta perbedaan yang tidak siginifikan yaitu sebesar 2,25\% pada satu skenario. Hasil tersebut menunjukkan bahwa implementasi perangkat lunak telah berhasil dan perangkat lunak tersebut dapat digunakan untuk kajian yang nyata. Kedepannya, penambahan berbagai fitur serta pengembangan model kajian perlu dilakukan untuk meningkatkan kemampuan perangkat lunak yang telah dibuat.

Kata kunci: Kajian dosis radiasi, perangkat lunak, lepasan zat radioaktif, lingkungan, IAEA SRS-19. 


\section{INTRODUCTION}

Public concern on ionizing radiation has increased since the Fukushima Dai-ichi Nuclear Power Plant accident. According to a study conducted by K. Hirose, radionuclides originated from the acciddent spreads mainly in the north part of the Northern Hemisphere atmosphere [1]. This was also confirmed by studies on marine biota in Malaysia [2] based on ERICA tool [3] and Indonesian ocean $[4,5]$. However, public concern on the safety of a nuclear facility rises all over the world and, hence, the related authority needs to response to this public concern.

National Nuclear Energy Agency (BATAN) as the government organization in Indonesia, which owns and operates three research reactors and related facilities that are mainly located at Serpong Nuclear Complex, is responsible to give adequate response to public concern, to protect public and environment from uncontrolled radioactive exposure. Several activities such as the development of online radiation monitoring system ${ }^{1}$ and the determination of nuclear emergency zone [6] have been conducted as a response to public concern.

A nuclear facility is designed, contstructed and operated based on a high safety standard defined by relevant Authority. In addition, as an owner of a facility or site, which might expose radiation risk into the environment and public, it is required to perform assessment on the impact of discharges of any radioactive substance into surrounding environment. The main objective of such assessment [7-10] is to ensure that radiation dose from radioactive substances, which possibly being released through atmosphere or water pathways, is still within dose limit criteria specified by relevant Regulatory Authority.

A method for assessing the impact of the release of radioactive substances into the environment based on simple generic environment model has been published by the International Atomic Energy Agency (IAEA) as Safety Report Series No. 19 (herein after referred to as SRS-19) [11]. The main objective of this guide is to provide simple calculation model for the purpose of evaluating suitable radioactive discharge limits into the atmosphere, surface water and sewerage systems. The guideline suggests an iterative approach for dose assessment. Firstly, it assumes the public is exposed at the release point and the dose is greater than the dose criterion. Next, the approach takes into account the dilution and dispersion of discharges into the environment based on generic environmental model.

In the SRS-19 guideline, formula of dose calculation model, generic default values of some input parameters, and precalculated value for several variables are provided to assist the dose calculation in conservative and pessimistic approach. Software called CROM code [12], which was developed by CIEMAT in collaboration with the Polytechnic University of Madrid, is also available as a tool for dose assessment. However, to our knowledge, some features, such as map, are not available in the software. In addition, it is not possible to add an own calculation model to the software. These limitations motivate us to develop our own software for dose assessment based on generic environment model described in SRS-19. The objectives of this study are to design and implement open source software for radiation dose assessment, and to verify its implementation against SRS-19 and CROM code. Future plans for further improvement are also discussed.

\section{THEORY}

Overview of the method for assessing radioactive discharges into atmosphere and surface water based on simple screening model is shown in Figure 1. In this method, when defining source term, the nature and magnitude of radioactive release must be defined separately for discharging into the atmosphere and surface water pathways. The next procedure is to estimate annual average radionuclide concentration in air or water based on the discharge rate defined in the source term. In addition to the concentration in the air, an annual average rate of radionuclide deposition in soil resulting from ground level and elevated sources of releases can be estimated by atmospheric dispersion model. On the other hand, the surface water model is used to estimate average

${ }^{I}$ Online radiation monitoring system, http://223.25.97.90/radmon 
radionuclide concentration in water body such as rivers, small and large lakes, estuaries and in coastal water.

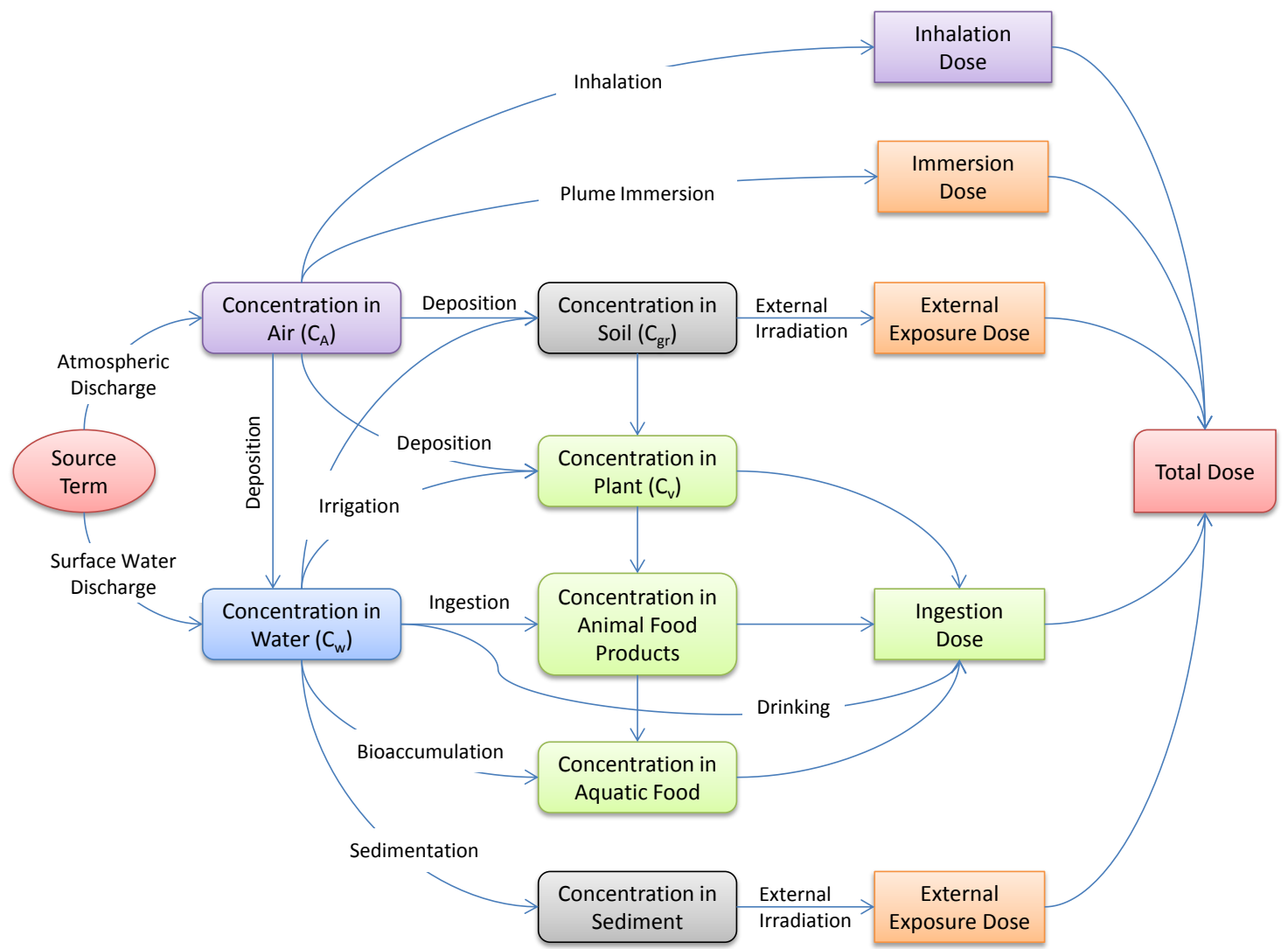

Figure 1. Overview of general assessment approach for atmospheric and water pathways [11].

After radionuclide concentration in air, water and ground deposition rate had been determined; an assessment of radionuclide concentration in terrestrial and aquatic food products needs to be performed. In this simplified generic environmental model, it is assumed an equilibrium conditions over a 30-years period. During the estimation of radionuclide concentration in terrestrial food products such as milk, meat and vegetables, radioactive material deposition from atmosphere, irrigation and uptake from soils are taken into accounts. For aquatic foods, accumulation of radioactive material into fresh water fish, marine fish and marine shellfish are considered.

The total dose is estimated for infant and adult critical group. The dose consists of inhallation of radioactive material, external dose due to immersion in the plume, ground deposition and exposure to sediment, and dose due to ingestion of terrestrial and aquatic food products. In the model, for simplicity, total dose is obtained by summing up the dose estimated from each pathway.

In this study, only mathematical formulas and input parameters, which were used during verification, are described. Consult SRS-19 guideline [11] for the rest and detail formulas, which were used to calculate radionuclide concentration in air, surface water, ground deposition, terrestrial and aquatic food products, and total dose for a critical group. A comprehenship list of generic values for every pathway, which can be used, instead of site-specific values is also available in the guideline.

The following mathematical formulas were taken from SRS-19 guideline [11]. In the guideline, Gaussian plume model is used to estimate long-term radionuclide concentration, which was continuously released through atmospheric pathway. The model depends on the relation between height of radionuclide release point $(H)$ and the height of building or structrure $\left(H_{B}\right)$ near the release point that affect airflow. When release height $H>2.5 H_{B}$, radionuclide air concentration at ground level $\left(C_{A}\right)$ can be calculated by 


$$
C_{A}=\left(P_{p}\right)(F)\left(Q_{i}\right) / u_{a}
$$

where $P_{p}$ is the fraction of the time during the year that the wind blows towards the receptor of interest in sector $p$ (16 sectors, e.g. N, NNE, NE), $u_{a}$ is the geometric mean of the wind speed at the height release and $Q_{i}$ is annual average discharge rate for radionuclide $i$. Values of Gaussian diffusion factor $F$ is given by the following equation

$$
F=\frac{12}{\sqrt{2 \pi^{3}}} \times \frac{\exp \left[-\left(H^{2} / 2 \sigma_{z}^{2}\right)\right]}{x \sigma_{z}}
$$

where $x$ is receptor distance in $\mathrm{m}$. Furthermore, vertical diffusion parameter $\sigma_{z}$ is given by equation (3) for release height less than $46 \mathrm{~m}$ and equation (4) if the release height is $46 \mathrm{~m}$ and above.

$$
\begin{gathered}
\sigma_{z}=0.06 x / \sqrt{1+0.0015 x} \\
\sigma_{z}=E x^{G}
\end{gathered}
$$

The constant $\mathrm{E}=0.215$ and $\mathrm{G}=0.885$ for release heights of $46-80 \mathrm{~m}, \mathrm{E}=0.265$ and $\mathrm{G}=0.818$ for release height that is greater than $80 \mathrm{~m}$.

If release point $H>2.5 H_{B}$ and receptor distance $x>2.5 \sqrt{A_{B}}$, then the following equation is used to calculate radionuclide air concentration $\left(C_{A}\right)$.

$$
C_{A}=\frac{P_{p} B Q_{i}}{u_{a}}
$$

Where $B$ Gaussion diffusion factor value for this condition, and can be calculated by

$$
B=\frac{12}{\sqrt{2 \pi^{3}}} \times \frac{1}{x \Sigma_{z}}
$$

where $\Sigma_{z}$ is given by the following formula.

$$
\Sigma_{z}=\left(\sigma_{z}^{2}+\frac{A_{B}}{\pi}\right)^{0.5} \text { for } x \geq 2.5 \sqrt{A_{B}}
$$

If release height $H \leq 2.5 H_{B}$ and receptor distance $x \leq 2.5 \sqrt{A_{B}}$, equations (8) and (9) will be used to calculate the radionuclide air concentration $\left(C_{A}\right)$. When the receptor is located at the same building with release point, radionuclide air concentration is given by

$$
C_{A}=\frac{B_{0} Q_{i}}{u_{a} x^{2}}
$$

where $B_{0}=30$. However, if the receptor is not located at the same building, the following equation

$$
C_{A}=\frac{P_{p} Q_{i}}{\pi u_{a} H_{B} K}
$$

where $K=1$ will be used to estimate the radionuclide concentration in air. After calculating $C_{A}$, the value of daily average ground deposition rate $\left(d_{i}\right)$ for radionuclide $i$ then can be calculated by

$$
d_{i}=\left(V_{d}+V_{W}\right) C_{A}
$$

where $V_{d}$ is dry deposition coefficient and $V_{W}$ is wet deposition coefficient.

Method for estimating radionuclide concentration in the river is based on analytical solutions to advection-diffusion equations describing radionuclide transport in surface waters with steady state uniform flow conditions[11], which is

$$
C_{t}=\frac{Q_{i}}{q_{r}} \exp \left(-\frac{\lambda_{i} x}{U}\right)
$$

where $C_{t}$ denotes fully mixed radionuclide concentration, $Q_{i}$ is annual average discharge rate for radionuclide $i$ (in $\mathrm{Bq} / \mathrm{s})$, and net freshwater velocity $U$ is given by 


$$
U=\frac{q_{r}}{B D}
$$

where $q_{r}$ is mean river flow rate, $B$ and $D$ are river width and depth (in $\mathrm{m}$ ). The total radionuclide concentration in surface water $\left(C_{w}\right.$, tot $)$ then can be calculated with the following equation (13),

$$
C_{w, \text { tot }}=C_{t} \times P_{r}
$$

where $P_{r}$ is a correction factor for the partial mixing, in which the value approaches unity as the downstream distance $x$ increases.

\section{METHODOLOGY}

\section{Software Design}

A generic approach for dose estimation is shown as a flowchart in Figure 2(a). In the flowchart, user needs to define assessment scenario, then specify calculation model along with known parameters. These parameters include site-specific values, constants e.g. radioactive decay constant, and other empirical values such as average consumption rate, habit and meteorological data. Given input parameters and calculation model then must be validated to ensure whether they meet assumption in calculation model, boundary condition and other requirements. If parameters and model are valid, user can continue to perform dose estimation and generate report, otherwise invalid parameters and/or models in the scenario must be reviewed.

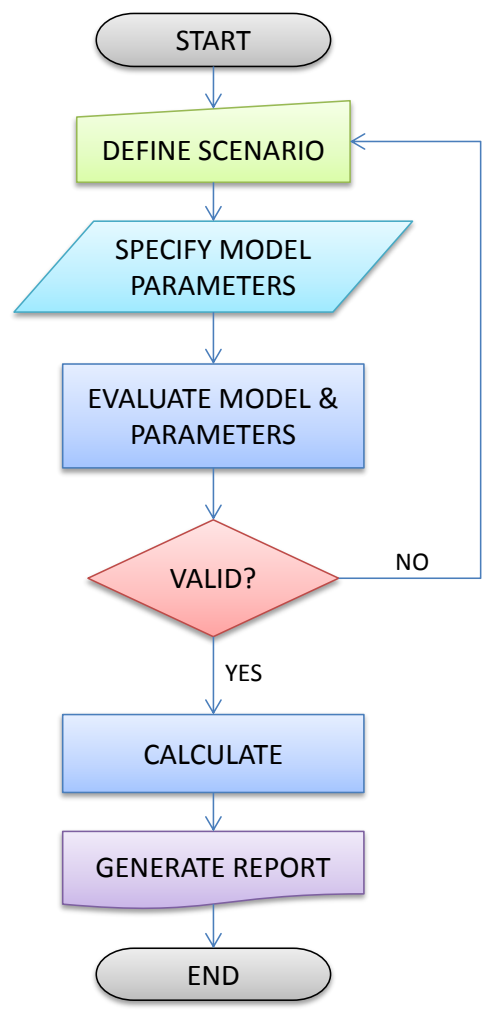

(a)

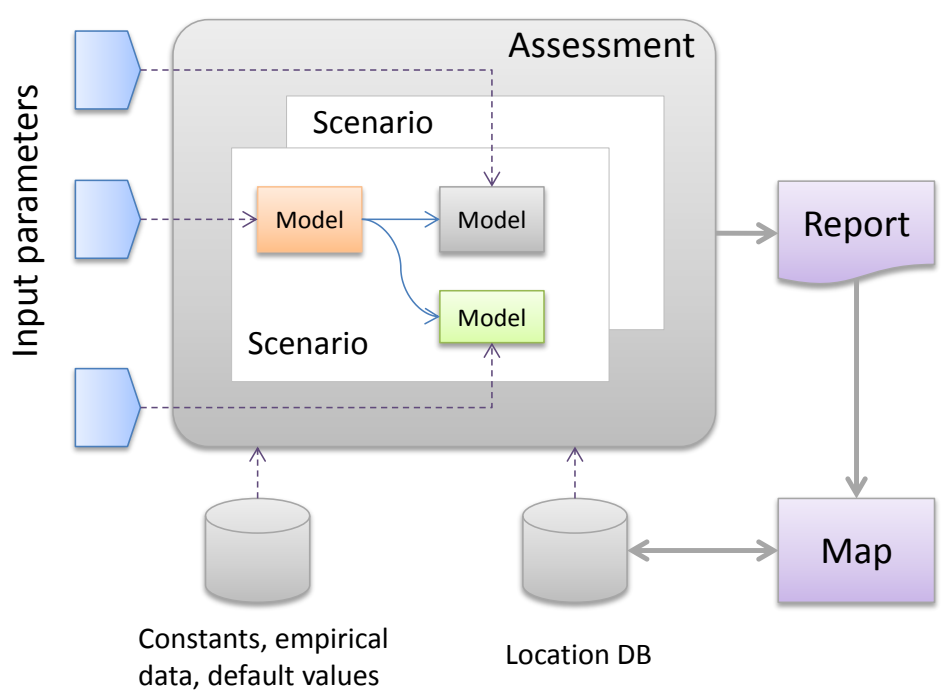

(b)

Figure 2. (a) Flowchart of dose estimation, (b) design of software code for dose assessment.

Conceptual design of the software for dose assessment that was implemented in this study is shown in Figure 2(b). Structured, component based approach is adopted in this design, in which an assessment is decomposed into several components called scenarios, then a scenario is decomposed into several sub components. A scenario consists of several models such as release point, 
atmospheric transport, discharge into surface water, animal feed and receptor point. User defined input parameter is associated with each model, while constants, empirical data and other default parameter values are stored in a database, which is widely available to all components. In addition, database for storing location with its geo-coordinate, name and other descriptions is provided. These locations can be obtained and displayed in the map along with the generated assessment report.

\section{Verification Method}

Verification of dose calculation model was performed using several examples provided in SRS-19. The purpose of the verification is to ensure that dose calculation model is correctly implemented in the developed software. In this study, three examples of radioactive releases through atmospheric pathways and one example for radioactive discharge into river were used and reported. These four scenarios were selected since they are similar to our situation in Serpong Nuclear Complex.

Table 1. Input parameters for Scenario 1 in which I-131 was released from $60 \mathrm{~m}$ stack

\begin{tabular}{clcc}
\hline Symbol & Description & Value & Unit \\
\hline Radionuclide & Radioactive material released to atmosphere & $\mathrm{I}-131$ & - \\
$Q_{i}$ & Annual average emission rate of radionuclide $i$ & 1 & $\mathrm{~Bq} / \mathrm{s}$ \\
$H$ & Release height & 60 & $\mathrm{~m}$ \\
$H_{B}$ & Height of the building that dominate the air flow & 20 & $\mathrm{~m}$ \\
& near the release point & 1000 & $\mathrm{~m}$ \\
$x$ & Receptor distance & $2 *$ & $\mathrm{~m} / \mathrm{s}$ \\
$u_{a}$ & Wind speed's annual geometric mean at the & & \\
& height of the release & $0.25^{*}$ & - \\
$P_{p}$ & Fraction of time in which the wind blows & & \\
& towards the receptor of interest in wind sector $p$ & $500^{*}$ & $\mathrm{~m} / \mathrm{day}$ \\
$V_{d}$ & Dry deposition coefficient & $500^{*}$ & $\mathrm{~m} / \mathrm{day}$ \\
\hline$V_{w}$ & Wet deposition coefficient & & \\
\hline
\end{tabular}

Table 2. Input parameters for Scenario 2 in which I-131 was released from small vent pipe

\begin{tabular}{clcc}
\hline Symbol & Description & Value & Unit \\
\hline Radionuclide & Radioactive material released to atmosphere & $\mathrm{I}-131$ & - \\
$Q_{i}$ & Annual average emission rate of radionuclide $i$ & 1 & $\mathrm{~Bq} / \mathrm{s}$ \\
$H$ & Release height & 20 & $\mathrm{~m}$ \\
$D$ & Vent pipe diameter & 0.5 & $\mathrm{~m}$ \\
$H_{B}$ & Height of the building that dominate the air flow & 20 & $\mathrm{~m}$ \\
& near the release point & 500 & $\mathrm{~m}^{2}$ \\
$A_{B}$ & Projected cross-sectional area of the building & & \\
& most influencing the flow of the plume & 5 and 1000 & $\mathrm{~m}$ \\
\hline
\end{tabular}

Table 3. Input parameters for Scenario 3 in which I-131 was released from a short stack on the top of a building

\begin{tabular}{clcc}
\hline Symbol & Description & Value & Unit \\
\hline Radionuclide & Radioactive material released to atmosphere & $\mathrm{I}-131$ & - \\
$Q_{i}$ & Annual average emission rate of radionuclide $i$ & 1 & $\mathrm{~Bq} / \mathrm{s}$ \\
$H$ & Release height & 33 & $\mathrm{~m}$ \\
$H_{B}$ & $\begin{array}{l}\text { Height of the building that dominate the air flow } \\
\text { near the release point }\end{array}$ & 30 & $\mathrm{~m}$ \\
$A_{B}$ & $\begin{array}{l}\text { Projected cross-sectional area of the building } \\
\text { most influencing the flow of the plume }\end{array}$ & 5000 & $\mathrm{~m}^{2}$ \\
& Receptor distance & 150 and & $\mathrm{m}$ \\
& & 1000 & \\
\hline
\end{tabular}


The first scenario (S1) is a release of Iodine-131 at average rate of $1 \mathrm{~Bq} / \mathrm{s}$ from $60 \mathrm{~m}$ stack to the atmosphere, and the plume is influenced by nearest building which has a height of $20 \mathrm{~m}$. In this scenario, the average air concentration and ground deposition rate at a farm located $1 \mathrm{~km}$ downwind from the release source need to be estimated. Input parameters are summarized in Table 1 , in which $*$ ) indicates that default values were used as input parameters since site-specific values were not available. These default input values also being used for the other two scenarios.

Scenario two (S2) assumed the same information as in S1 except the release point was a small vent pipe in the side of a building. In addition, a residence located $5 \mathrm{~m}$ from released point must also be considered. The input parameters for S2 are listed in Table 2. The last scenario for atmospheric pathways (S3: scenario 3) was a release of Iodine-131 from $33 \mathrm{~m}$ stack located at a 30 $\mathrm{m}$ building and a frontal cross-sectional area of $5000 \mathrm{~m}^{2}$. Receptor points were the same farm and residence, which is located $150 \mathrm{~m}$ away from the release point. The complete input parameters for S3 are shown in Table 3.

Table 4. Input parameters for Scenario 4 where Cs-137 is to be released to a relatively small river

\begin{tabular}{clcc}
\hline Symbol & Description & Value & Unit \\
\hline Radionuclide & Released radioactive material & Cs-137 & - \\
$Q_{i}$ & Average radionuclide discharge rate into river & 1170 & $\mathrm{~Bq} / \mathrm{s}$ \\
$F$ & Flow rate of the liquid effluent & 1 & $\mathrm{~m}^{3} / \mathrm{s}$ \\
$\bar{B}$ & River width under a mean annual river flow rate & 50 & $\mathrm{~m}$ \\
$x$ & Receptor distance & 1000 & $\mathrm{~m}$ \\
\hline
\end{tabular}

The fourth scenario (S4) is a release of Caesium-137 with annual discharge rate of $3.7 \times 10^{10}$ $\mathrm{Bq}$ into the small river. If effluent discharge rate is $1 \mathrm{~m}^{3} / \mathrm{s}$ and estimated river width is $50 \mathrm{~m}$, then calculate the concentration of ${ }^{137} \mathrm{Cs}$ at one kilometer downstream from release point. Input parameters for this scenario is listed in Table 4.

The output of radionuclide concentration estimated in each scenario is compared to the result of manual calculation as described in the example calculations (SRS-19 annex IV). Additionally, the result also compared with the output of CROM code software[12], another software implementing calculation model described in IAEA safety report series number 19. Finally, to evaluate the magnitude of the difference, the output of SRS-19 and CROM code are divided by estimation result of this study.

\section{RESULTS AND DISCUSSION}

\section{Software Implementation}

A screenshot of the developed software is shown in Figure 3, and the source code is available from $\mathrm{GitHub}^{2}$. The software was developed using $\mathrm{C}++$ programming language, open source Qt framework ${ }^{3}$, Marble library ${ }^{4}$ for displaying map and SQLite ${ }^{5}$ for storing parameters. It consists of five main graphical user interface (GUI) components, which are menu and toolbar at the top side, assessment and scenario list at the left side window (assessment explorer), model list at the right side window, output window at the bottom and main display at the middle. In this figure, map [13] is displayed at the main window. In the displayed map, user can pick up location along with its geo-coordinate (latitude and logitude), calculates straight distance between two places, e.g. distance between relase source and receptor, and registers the location into database for later use. The main window also can be used for displaying scenario and report (see Figure 4 (a) and (b)).

\footnotetext{
109

${ }^{2}$ Source code is available at https://github.com/ipsusila/radenv

${ }^{3}$ Qt Framework, https://www.qt.io

${ }^{4}$ KDE Marble, https://marble.kde.org

${ }^{5}$ SQLite, http://www.sqlite.org
} 


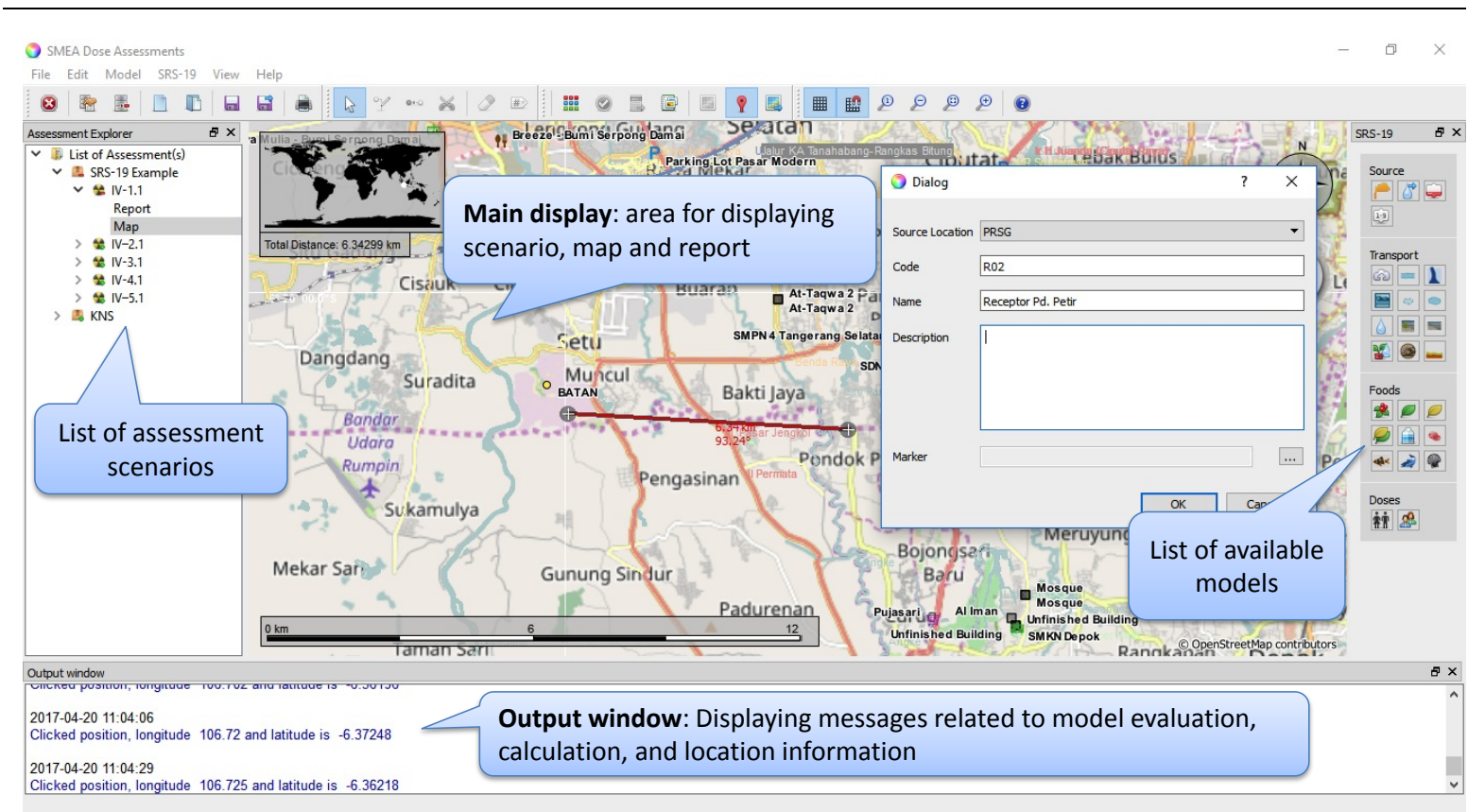

Figure 3. Screenshot of the developed software with map display for calculating distance, picking location and its coordinate.

Estimation of radionuclide concentration and total dose are performed per scenario, which mimics general assessment approach shown in Figure 1. At first, user must define an assessment in assessment explorer, create a scenario placeholder with unique name and give a short description about the scenario. Next, as shown in Figure 4(a), user must define the dose calculation scenario by combining several models. One of the models must be a source model describing the characteristic of released source and other related parameters such as released radionuclide(s), discharge rate, volumetric airflow rate, and stack height. The other model must be transport model which defines how radionuclide being transported from released source to a receptor. The transport model includes atmospheric pathway, ground deposition and water pathways such as river, estuarine, lake, coastal water, irrigation and surface sewage pathway. Optionally, food models such as animal feed, crop, meat, milk, freshwater fish, marine fish, and marine shellfish can be added to scenario when calculating radionuclide concentration accummulated in food products. Finally, for total dose estimation in population, dose calculation model for infant and adult are provided.

After a scenario has been created, valid input parameters for each model in the scenario must be defined. If site specific values are available, those values must be used, otherwise, default values will be used. A GUI for setting input parameters is provided for each model and can be displayed by double-clicking the model. When default value is available for a parameter, that value is set automatically and later can be changed by user to match site specific needs. The next step is validation of all input parameters. Any warning or error message related to model and input parameter will be displayed in the output window. If all the parameters are valid, then radionuclide concentration and/or total dose at a specific receptor location can be calculated. The calculation results along with intermediate parameters will be displayed in the report as displayed in Figure 4(b). The calculation results are also displayed on the map. 


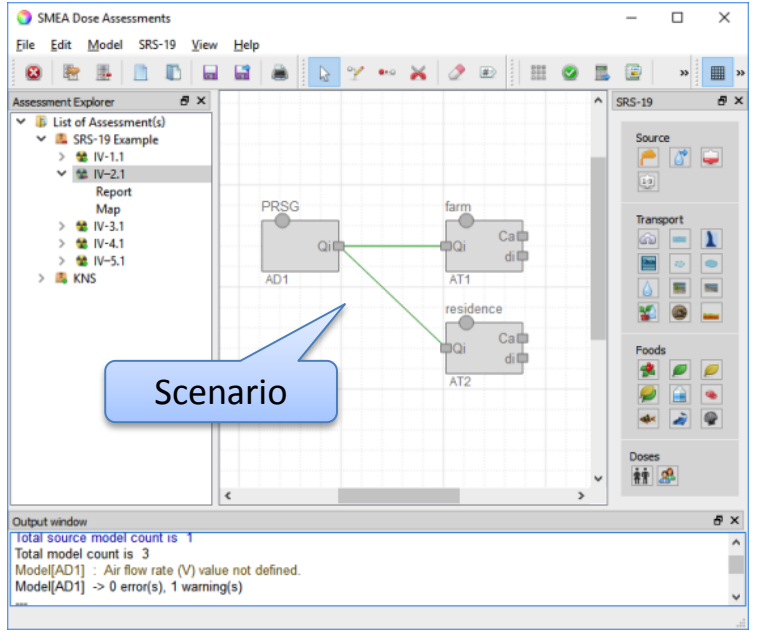

(a)

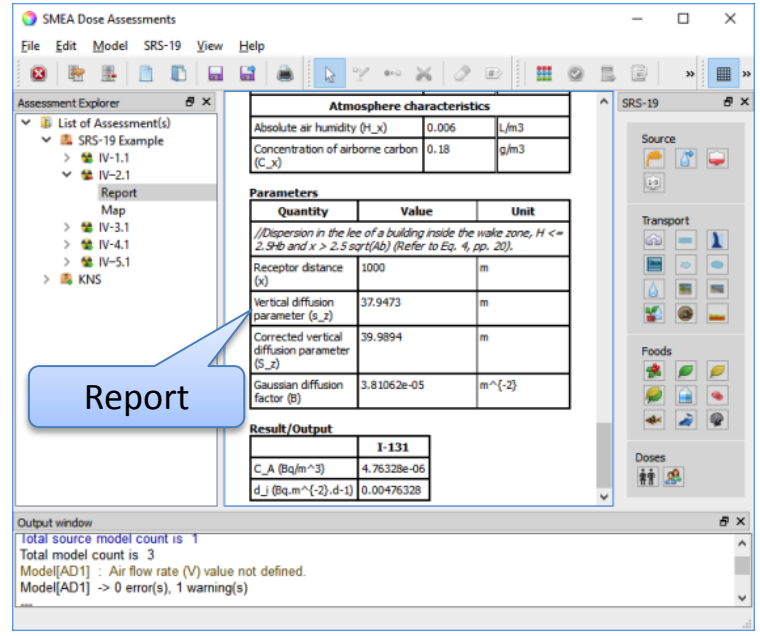

(b)

Figure 4. (a) Scenario with a source model and two transport models, and (b) Calculation result.

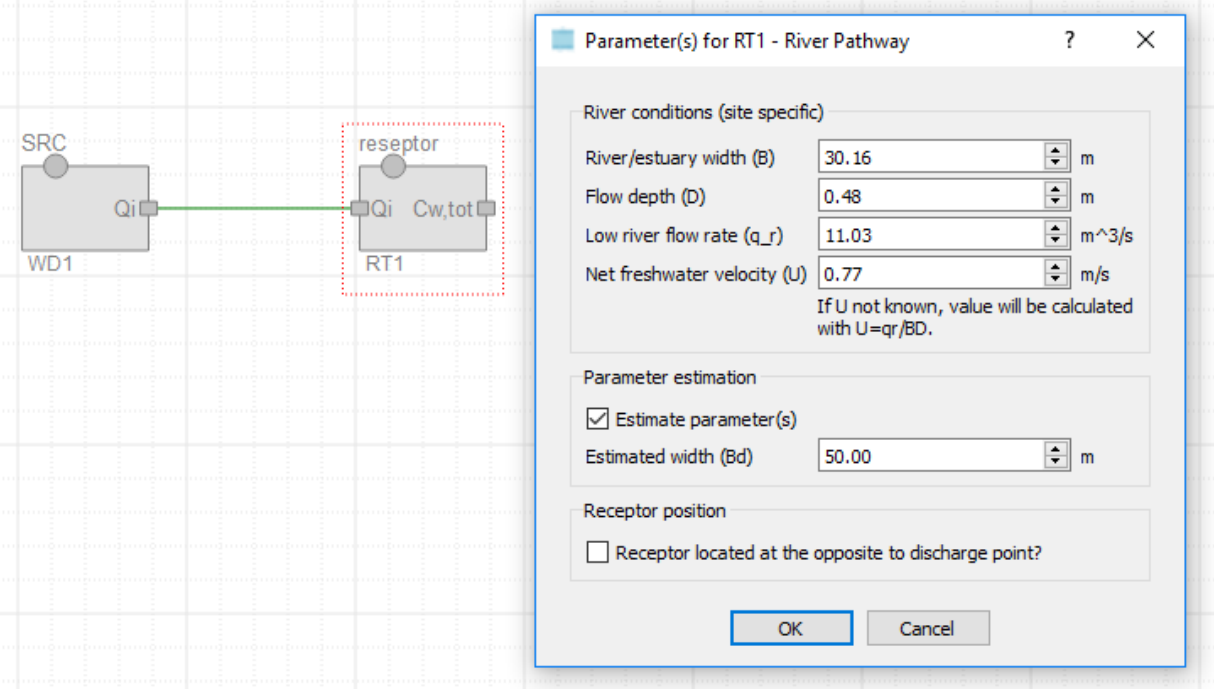

Figure 5. Example scenario with input parameter setup

All the described procedures were implemented based-on flowchart in Figure 2. Scenario definition, input parameter setup and validation, radionuclide concentration and total dose estimation are performed through GUI-based operation. When setting input parameters for a scenario, the availability of default values for some parameters reduced user inputs. In addition, parameters are groupped by model (source, transport, food) to assists user inputs. These features enable even a novice user to perform assessment intuitively and easily.

\section{Verification Results}

Comparison of calculation output for atmospheric patways with different release parameters and receptor locations are shown in Table 5 to Table 7. These tables consist of calculated intermediate parameters, annual average concentration in air at ground level and daily average deposition rate of I-131obtained from example calculation result in Safety Report Series no. 19, CROM software and this study. Values calculated by CROM software and the software developed in this study are equal for these scenarios, but slightly different with values shown in SRS-19 example calculation result. In SRS-19, Gaussian diffusion factors $(F$ or $B)$ are pre-calculated for a specific receptor distance $x$ and several groups of release height $(H)$, i.e. $0-5 \mathrm{~m}, 6-15 \mathrm{~m}, 16-25 \mathrm{~m}$, 26-35 m, 36-45 m, $46-80 \mathrm{~m},>80 \mathrm{~m}$ or building area $\left(A_{B}\right)$, i.e. $0-100 \mathrm{~m}^{2}, 101-400 \mathrm{~m}^{2}, 401-800 \mathrm{~m}^{2}$, 
$801-1200 \mathrm{~m}^{2}, 1201-1600 \mathrm{~m}^{2}, 1601-2000 \mathrm{~m}^{2}, 2001-3000 \mathrm{~m}^{2}, 3001-4000 \mathrm{~m}^{2}, 4001-600 \mathrm{~m}^{2},>6000$ $\mathrm{m}^{2}$ [11]. As the result, Gaussian diffusion factor within a group will be the same, e.g. $F=1 \times 10^{-5}$ $\mathrm{m}^{-2}$ if radionuclide was released from stack which height is greater than $80 \mathrm{~m}$, and receptor location is $1 \mathrm{~km}$ away from the stack. In case of CROM and the developed software, Gaussian diffusion factors $F$ or B are directly calculated, and in this case $F$ value is $1.296 \times 10^{-5} \mathrm{~m}^{-2}$, and slightly changing whenever release height or building area and receptor distance changes.

Table 5. Comparison of scenario 1 output: intermediate parameters, annual average concentration, and daily average deposition rate of I-131

\begin{tabular}{|c|c|c|c|c|c|}
\hline \multirow{2}{*}{ Symbol } & \multirow{2}{*}{ Description } & \multicolumn{3}{|c|}{ Results } & \multirow{2}{*}{ Unit } \\
\hline & & SRS-19 & CROM & This Study & \\
\hline$\sigma_{z}$ & Vertical diffusion parameter & $*)$ & $9.715 \times 10^{1}$ & $9.715 \times 10^{1}$ & $\mathrm{~m}$ \\
\hline$F$ & $\begin{array}{l}\text { Gaussian diffusion factor } \\
\text { appropriate for the height } \\
\text { Hand receptor distancex }\end{array}$ & $1 \times 10^{-5}$ & $1.296 \times 10^{-5}$ & $1.296 \times 10^{-5}$ & $\mathrm{~m}^{-2}$ \\
\hline$C_{A}$ & $\begin{array}{l}\text { Annual average concentration } \\
\text { of radionuclide in } \operatorname{air}(a t \\
\text { ground level) }\end{array}$ & $1.3 \times 10^{-6}$ & $1.620 \times 10^{-6}$ & $1.620 \times 10^{-6}$ & $\mathrm{~Bq} / \mathrm{m}^{3}$ \\
\hline$d_{i}$ & $\begin{array}{l}\text { Daily average radionuclide } \\
\text { deposition rate to the ground } \\
\text { surface from both dry and wet } \\
\text { processes }\end{array}$ & $1.3 \times 10^{-3}$ & $1.620 \times 10^{-3}$ & $1.620 \times 10^{-3}$ & Bq. $\mathrm{m}^{-2} \cdot$ day $^{1}$ \\
\hline
\end{tabular}

Note:

*) $\sigma_{z}$ is not calculated since the value of $F$ is obtained from pre-calculated values according to height $(H)$

Table 6. Comparison of scenario 2 output: intermediate parameters, annual average concentration, and daily average deposition rate of $\mathrm{I}-131$ at residence and farm location

\begin{tabular}{|c|c|c|c|c|c|}
\hline Symbol & Description & SRS-19 & $\begin{array}{l}\text { Results } \\
\text { CROM }\end{array}$ & This Study & Unit \\
\hline \multicolumn{6}{|c|}{ Residence } \\
\hline$C_{A}$ & $\begin{array}{l}\text { Annual average concentration } \\
\text { of radionuclide in } \operatorname{air}(a t \\
\text { ground level) }\end{array}$ & 0.6 & 0.6 & 0.6 & $\mathrm{~Bq} / \mathrm{m}^{3}$ \\
\hline$d_{i}$ & $\begin{array}{l}\text { Daily average radionuclide } \\
\text { deposition rate to the ground } \\
\text { surface from both dry and wet } \\
\text { processes }\end{array}$ & 600 & 600 & 600 & Bq. $\mathrm{m}^{-2} \cdot$ day $^{-1}$ \\
\hline \multicolumn{6}{|c|}{ 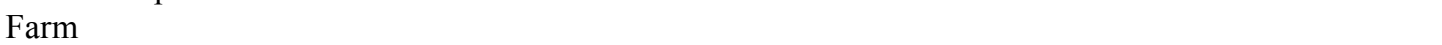 } \\
\hline$\sigma_{z}$ & Vertical diffusion parameter & $*)$ & $3.795 \times 10^{1}$ & $3.795 \times 10^{1}$ & $\mathrm{~m}$ \\
\hline$\Sigma_{z}$ & $\begin{array}{l}\text { Corrected vertical diffusion } \\
\text { parameter }\end{array}$ & $*)$ & & $3.999 \times 10^{1}$ & $\mathrm{~m}$ \\
\hline$B$ & $\begin{array}{l}\text { Gaussian diffusion factor } \\
\text { corrected for dispersion in the } \\
\text { lee of a building inside the } \\
\text { wake zone }\end{array}$ & $4 \times 10^{-5}$ & $3.811 \times 10^{-5}$ & $3.811 \times 10^{-5}$ & $\mathrm{~m}^{-2}$ \\
\hline$C_{A}$ & $\begin{array}{l}\text { Annual average concentration } \\
\text { of radionuclide in } \operatorname{air}(a t \\
\text { ground level) }\end{array}$ & $5 \times 10^{-6}$ & $4.763 \times 10^{-6}$ & $4.763 \times 10^{-6}$ & $\mathrm{~Bq} / \mathrm{m}^{3}$ \\
\hline$d_{i}$ & $\begin{array}{l}\text { Daily average radionuclide } \\
\text { deposition rate to the ground } \\
\text { surface from both dry and wet } \\
\text { processes }\end{array}$ & $5 \times 10^{-3}$ & $4.763 \times 10^{-3}$ & $4.763 \times 10^{-3}$ & Bq. $\mathrm{m}^{-2} \cdot$ day $^{-1}$ \\
\hline
\end{tabular}

Note:

*) $\sigma_{z}$ and $\Sigma_{z}$ were not calculated since the value of $B$ was estimated from pre-calculated values based on building area $(A)$ and receptor distance $(x)$ 
Table 7. Comparison of scenario 3 output: intermediate parameters, annual average concentration, and daily average deposition rate of $\mathrm{I}-131$ at residence and farm location

\begin{tabular}{|c|c|c|c|c|c|}
\hline Symbol & Description & SRS-19 & $\begin{array}{l}\text { Results } \\
\text { CROM }\end{array}$ & This Study & Unit \\
\hline \multicolumn{6}{|c|}{ Residence } \\
\hline$C_{A}$ & $\begin{array}{l}\text { Annual average concentration } \\
\text { of radionuclide in air(at ground } \\
\text { level) }\end{array}$ & $1.3 \times 10^{-3}$ & $1.326 \times 10^{-3}$ & $1.326 \times 10^{-3}$ & $\mathrm{~Bq} / \mathrm{m}^{3}$ \\
\hline$d_{i}$ & $\begin{array}{l}\text { Daily average radionuclide } \\
\text { deposition rate to the ground } \\
\text { surface from both dry and wet } \\
\text { processes }\end{array}$ & 1.3 & 1.326 & 1.326 & Bq.m $m^{-2} \cdot$ day $^{-1}$ \\
\hline \multicolumn{6}{|c|}{ 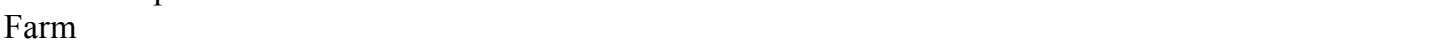 } \\
\hline$\sigma_{z}$ & Vertical diffusion parameter & $*)$ & $3.795 \times 10^{1}$ & $3.795 \times 10^{1}$ & $\mathrm{~m}$ \\
\hline$\Sigma_{z}$ & $\begin{array}{l}\text { Corrected vertical diffusion } \\
\text { parameter }\end{array}$ & $*)$ & & $5.506 \times 10^{1}$ & $\mathrm{~m}$ \\
\hline$B$ & $\begin{array}{l}\text { Gaussian diffusion factor } \\
\text { corrected for dispersion in the } \\
\text { lee of a building inside the } \\
\text { wake zone }\end{array}$ & $4 \times 10^{-5}$ & $2.768 \times 10^{-5}$ & $2.768 \times 10^{-5}$ & $\mathrm{~m}^{-2}$ \\
\hline$C_{A}$ & $\begin{array}{l}\text { Annual average concentration } \\
\text { of radionuclide in air(at ground } \\
\text { level) }\end{array}$ & $5 \times 10^{-6}$ & $3.460 \times 10^{-6}$ & $3.460 \times 10^{-6}$ & $\mathrm{~Bq} / \mathrm{m}^{3}$ \\
\hline$d_{i}$ & $\begin{array}{l}\text { Daily average radionuclide } \\
\text { deposition rate to the ground } \\
\text { surface from both dry and wet } \\
\text { processes }\end{array}$ & $5 \times 10^{-3}$ & $3.460 \times 10^{-3}$ & $3.460 \times 10^{-3}$ & Bq. $\mathrm{m}^{-2} \cdot \mathrm{day}^{-1}$ \\
\hline
\end{tabular}

Note:

*) $\sigma_{z}$ and $\Sigma_{z}$ were not calculated since the value of $B$ was estimated from pre-calculated values based on building area $(A)$ and receptor distance $(x)$

Table 8. Comparison of scenario 4 output: intermediate parameters and total Cs- 137 concentration in water

\begin{tabular}{|c|c|c|c|c|c|}
\hline Symbol & Description & SRS-19 & $\begin{array}{l}\text { Results } \\
\text { CROM }\end{array}$ & This Study & Unit \\
\hline $\bar{q}_{r}$ & Mean annual river flow rate & 30 & - & - & $\mathrm{m}^{3} / \mathrm{s}$ \\
\hline$q_{r}$ & $\begin{array}{l}30 \text { year low annual river flow } \\
\text { rate }\end{array}$ & 10 & 11.080 & 11.025 & $\mathrm{~m}^{3} / \mathrm{s}$ \\
\hline$B$ & River width & 28.8 & 29.980 & 30.164 & $\mathrm{~m}$ \\
\hline$D$ & Flow depth & 0.48 & 0.496 & 0.477 & $\mathrm{~m}$ \\
\hline$L_{z}$ & $\begin{array}{l}\text { Vertical complete mixing } \\
\text { distance }\end{array}$ & 3.4 & 3.333 & 3.336 & $\mathrm{~m}$ \\
\hline$U$ & Net freshwater velocity & 0.72 & 0.745 & 0.767 & $\mathrm{~m} / \mathrm{s}$ \\
\hline$A$ & Partial mixing index & 0.87 & - & 0.786 & \\
\hline$C_{t}$ & $\begin{array}{l}\text { Fully mixed radionuclide } \\
\text { concentration (uncorrected) }\end{array}$ & 117 & - & 106.122 & $\mathrm{~Bq} / \mathrm{m}^{3}$ \\
\hline$P_{r}$ & $\begin{array}{l}\text { Correction factor for the partial } \\
\text { mixing }\end{array}$ & 2.7 & 2.791 & 2.842 & - \\
\hline$C_{w, t o t}$ & $\begin{array}{l}\text { Total radionuclide } \\
\text { concentration in water }\end{array}$ & 316 & 294.800 & 301.586 & $\mathrm{~Bq} / \mathrm{m}^{3}$ \\
\hline
\end{tabular}

In Table 8, calculated intermediate parameters and total Cs-137 concentration in water are compared. Calculated values of $C_{w, \text { tot }}$ are $316 \mathrm{~Bq} / \mathrm{m}^{3}$ in SRS-19, which is greater than the result of this study, $301.586 \mathrm{~Bq} / \mathrm{m}^{3}$ in this study and $294.800 \mathrm{~Bq} / \mathrm{m}^{3}$ in CROM software, slightly lower than the result of this study. These differences occur as a result of different approach for estimating 
annual river flow rate $\left(q_{r}\right)$. In SRS-19, pre-calculated nearest value is used, but in this study, a linear interpolation is used when estimating $q_{r}$.

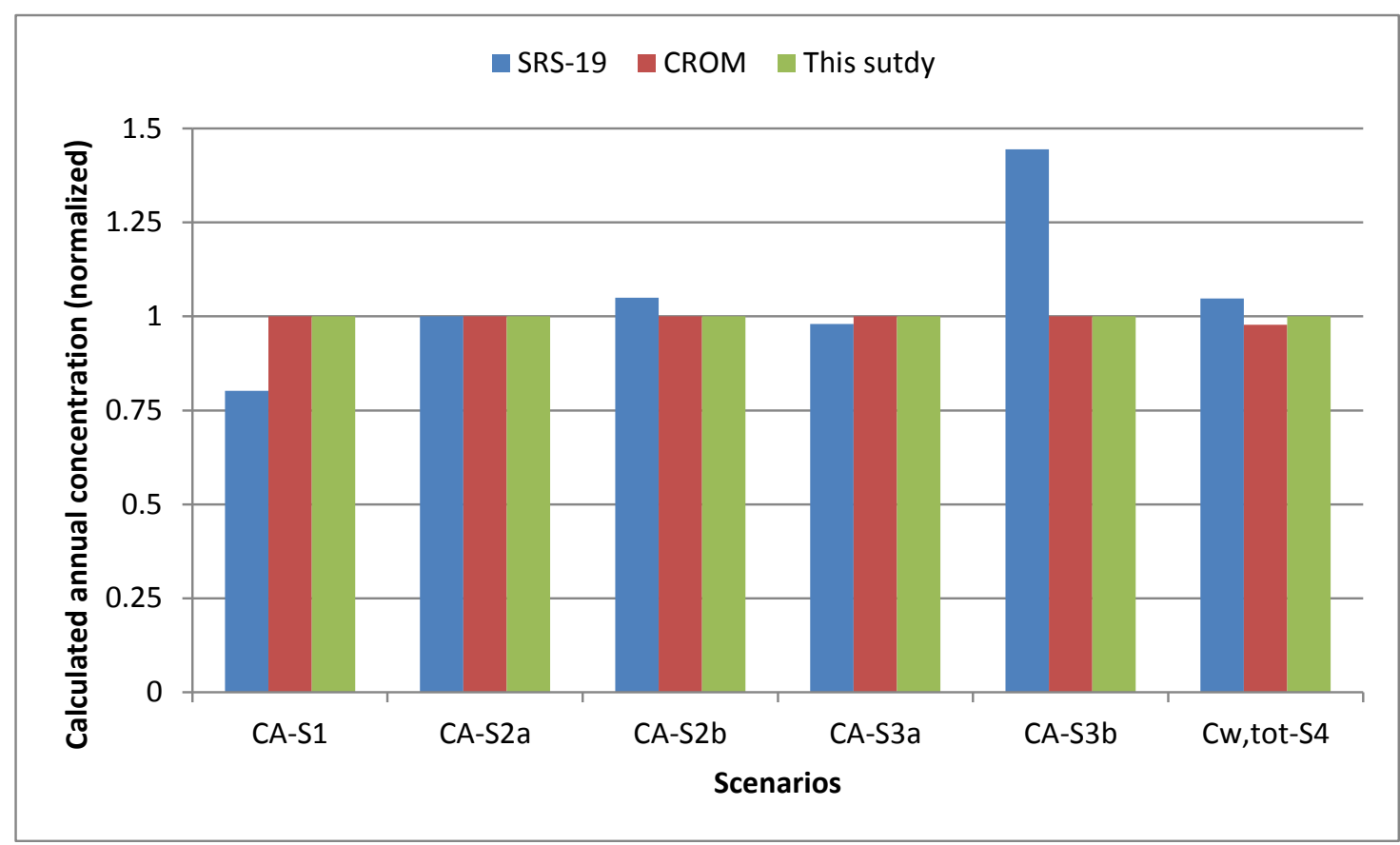

Figure 6. Comparison of calculated annual radionuclide concentration in air $\left(\mathrm{C}_{\mathrm{A}}\right)$ and water $\left(\mathrm{C}_{\mathrm{w}, \text { tot }}\right)$ for each scenario (S1-S4). The value is normalized by the result obtained from the developed software.

Figure 6 shows comparison of calculated annual radionuclide concentration in air and water for each scenario (S1-S4). In the figure, all values are normalized with the result obtained in this study. The difference with calculation result in SRS-19 is between $19.75 \%$ (scenario 1) to $44.51 \%$ (scenario 3). In SRS-19, since its purpose is to let user performs estimation easily without using complicated equation and/or software, during the calculation it uses pre-calculated value, and if the exact value is not available, nearest available value will be used. Thus, estimation results may significantly differ both with CROM and result of this study. When comparing with the result of CROM software, estimated values are equal for scenario 1 to scenario 3 , and for scenario 4 , the difference is only $2.25 \%$. This demonstrates that calculation models described in SRS-19 are implemented correctly in the developed software.

We have demonstrated the features and functionality of developed software. The implementation, which adopts data-flow diagram concept is based on our previous work [14] and was also inspired by $[15,16]$. In addition, calculations model are implemented as plug into facilitate addition of new calculation model other than models described in SRS-19. Verification against SRS-19 example calculation, which has been done in this study demonstrates the validity of our implementation. It implies that our software can be used to estimate radiation dose in real scenario, e.g. assessing the impact of discharge of radioactive substances in Serpong Nuclear Complex. In this case, to improve the estimation results site specific values should be used. For example, when estimating radiation dose from atmospheric pathways, instead of default values provided in SRS19 , the meteorological data gathered by our online radiation and monitoring system could be used. In the future, web-based platform for community interaction [17], requirements, model evaluation techniques as described by Laniak et al. in integrated environmental modeling [18], and new calculation model [19] may be added to the software. Furthermore, estimation of radiation dose in an area could be added istead of dose at a specific receptor point. 


\section{CONCLUSION}

A software code for assessing radiation dose due to release of radioactive substances to environment has been developed and verified. A component based, data-flow diagram was used to express model of release source, pathways and receptor. Map also provided and can be used for calculating source to receptor distance and for displaying estimation result along with scenario description and input parameters. The calculation model for estimating radiation dose at a specific receptor location is based on formulas in IAEA safety reports series no. 19 and the result has been verified using provided examples and compared with CROM software. Verification result with maximum difference of $2.25 \%$ with CROM software demonstrates the correctness of our implementation and implies that the developed software is ready for use in real scenario.

\section{ACKNOWLEDGEMENT}

The authors wish to thank Dr. Syahrir for many suggestions and valuable discussions during the implementation of the software, A. Wijayanto and M.M. Farid for their assistance in providing default values for calculation model.

\section{REFERENCES}

1. Hirose K. 2011 Fukushima Dai-ichi nuclear power plant accident: summary of regional radioactive deposition monitoring results. J. Environ. Radioact. 2012.111:13-17.

2. Sin H.S., Sarmani S., Siong K.K. Radiological impact assessment of Fukushima Daiichi nuclear accident on Malaysian marine biotas via ocean partway using ERICA code system. Sains Malays. 2014. 43(10):1565-1571.

3. Larsson C.M. An overview of the ERICA Integrated Approach to the assessment and management of environmental risks from ionising contaminants. J. Environ. Radioact.2008. 99(9):1364-1370.

4. Suseno H., Prihatiningsih W.R. Monitoring ${ }^{137} \mathrm{Cs}$ and ${ }^{134} \mathrm{Cs}$ at marine coasts in Indonesia between 2011 and 2013. Mar. Pollut. Bull. 2014. 88(1):319-324.

5. Suseno H., Wahono I.B., Muslim. Radiocesium monitoring in Indonesian waters of the Indian Ocean after the Fukushima nuclear accident. Mar. Pollut. Bull.. 2015. 97(1):539543.

6. Udiyani P.M., Kuntjoro S. Penentuan Zona Kedaruratan Nuklir Luar Tapak (off-site) di Indonesia. J. Teknol. Pengelolaan Limbah. 2015.17(2):58-65.

7. Aliyu, A.S.; Ramli, A.T. \& Saleh, M.A. Environmental impact assessment of a new nuclear power plant (NPP) based on atmospheric dispersion modeling. Stoch. Environ. Res. Risk. Assess. 2014. 28(7):1897-1911.

8. Udiyani P.M., Kuntjoro S., Pane J.S. Aktivitas dan Konsekuensi Dispersi Radioaktif untuk Daerah Kota dan Pedesaan. Jurnal Pengembangan Energi Nuklir. 2015.17(2):79-86.

9. Chambers S.D., Galeriu D., Williams A.G., Melintescu A., Griffiths A.D., Crawford J., et al. Atmospheric stability effects on potential radiological releases at a nuclear research facility in Romania: Characterising the atmospheric mixing state. J. Environ. Radioact. 2016.154:68-82.

10. Garrick B.J., Stetkar J.W., Bembia P.J. Quantitative risk assessment of the New York state operated west valley radioactive waste disposal area. Risk Anal. 2010. 30(8):12191230 .

11. IAEA Generic Models for Use in Assessing the Impact of Discharge of Radioactive Substances to the Environment. Safety Reports Series No. 19. Vienna, Austria:International Atomic Energy Agency; 2001.

12. Robles B., Suáñez A., Mora J.C., Cancio D. Modelos implementados en el código CROM.Madrid, Spain: CIEMAT. 2007 
13. Haklay M., Weber P. OpenStreetMap: User-Generated Street Maps, IEEE Pervasive Comput. 2008. 7(4):12-18.

14. Susila IP., Kanoh S., Miyamoto K., Yoshinobu T. xBCI: a generic platform for development of an online BCI system. IEEJ T. Electr. Electr. 2010. 5(4):467-473.

15. Napier B.A. GENII version 2 users' guide. Pacific Northwest National Laboratory report PNNL-14583 Rev. 3; 2011.

16. Whelan G., Kim K., Pelton M.A., Castleton K.J., Laniak G.F., Wolfe K., Parmar R., Babendreier J., Galvin M. Design of a component-based integrated environmental modeling framework. Environ. Model. Softw. 2014. 55:1-24.

17. Walker J.D., Chapra S.C. A Client-side Web Application for Interactive Environmental Simulation Modeling Environ. Model. Softw. 2014.55:49-60.

18. Laniak G.F., Olchin G., Goodall J., Voinov A., Hill M., Glynn P., Whelan G., Geller G., Quinn N., Blind M., Peckham S., Reaney S., Gaber N., Kennedy R., Hughes A. Integrated environmental modeling: a vision and roadmap for the future. Environ. Model. Softw. 2013. 39:3-23.

19. Aliyu A.S., Ramli A.T., Garba N.N., Ismaila A., Abba H.T., Saleh M.A., Aliyu M. Assessment of Environmental and Human Health Impacts of a New Nuclear Power Plant using Hybrid Single-Particle Langrangian Air Dispersion Model. Indian J Sci Technol. 2015. 8(S9):489-500. 